\title{
Optimal Tax Deferral Choices In The Presence Of Changing Tax Regimes
}

Terrance Jalbert, (Email: jalbert@hawaii.edu), University of Hawaii at Hilo Eric Rask, (Email: rask@ hawaii.edu), University of Hawaii at Hilo Mercedes Jalbert (Email: mercedesjalbert@yahoo.com), The IBFR

\begin{abstract}
In this paper the attractiveness of tax-deferred and non-deferred investments in periods of changing tax regimes are examined. Specifically the desirability of deferring taxes given one's current tax rate, estimate of future tax rates, number of years until retirement, and the expected rate of return on investment is explored. Under some combinations of tax rates and investment horizons, tax deferral is found to be undesirable while in others it is found to be desirable. Using the formulas and tables developed here, an individual can identify the rate of return on investment at which he is indifferent between deferring and not deferring, rates at which tax deferral is preferred and rates at which tax deferral is inferior. In addition, the sensitivity of the decision to the timing of future tax rate changes is explored. This research provides investors a more comprehensive understanding of the factors that determine optimal tax deferral choices and will permit investors to make better tax deferral decisions.
\end{abstract}

\section{INTRODUCTION}

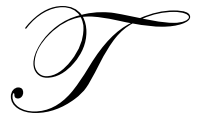

ax deferred investment is a common method for people to save money for retirement. The benefit of deferring taxes is that one has more money to invest until retirement, thereby gaining from the time value of money. At retirement, taxes are paid on any balances that have not been previously taxed. There are at least four risks associated with investing in tax deferred accounts. The first risk is that, in contrast to other investments, any losses on investment in a deferred account are not deductible against current income. The second risk is that the individual needs access to the funds prior to retirement, requiring the individual to pay a penalty for early withdrawal. The third risk is that tax rates will increase between the time of deposit and withdrawal, resulting in deferral to a higher tax rate. The fourth risk is that the individual's income will increase sufficiently in retirement to move the individual to a higher tax bracket. The focus of this paper is on the third and fourth risks, that tax rates or brackets will change.

There are a number of tax deferral savings vehicles available to investors. The Traditional Individual Retirement Arrangement (IRA) was first introduced by the Retirement Income Security Act (ERISA) of 1974. Its goal was to encourage increased savings by tax payers. Traditional IRAs allow individuals younger than $701 / 2$ years of age to deduct a prescribed amount of income from his/her taxable income by placing the money into an account targeted for use in their retirement years. The investor must meet certain income limitations to qualify to take the deduction. If the individual takes the money out of the account after age 59.5, the individual pays ordinary income taxes on the amount of money received. In the event that an individual takes the money out of the account prior to age 59.5 , a $10 \%$ penalty is assessed on the withdrawals and the remainder is taxed as ordinary income. Individuals are required to begin taking money out of a traditional IRA by age $70 \frac{1}{2}$ years. More recently, Roth IRA's were introduced. Contributions to Roth IRA's are not tax-deductible, and there are no age restrictions on contributions. However, returns from a Roth IRA are tax free. Like traditional IRA's, Roth IRA's are subject to income and filing status limitations (U.S Internal Revenue Service 2004). Other contributory plans include non-deductible IRA's, 401K's 403B's, 457's, Simplified Employee Pensions (SEP) and The Saving Incentive Match Plan for Employees (SIMPLE). Each of these plans has its own advantages, disadvantages, rules and limitations. 
Each year, millions of taxpayers are faced with the question "Should I defer taxes on my retirement savings?" At first glance tax-deferral appears to be the best choice in all cases, but questions about the benefits of deferring arise when tax rates and investment returns are expected to follow certain patterns in the future and when the time to retirement is shorter. In certain instances, it may not be beneficial to defer taxes. This holds particularly true if the individual expects low returns on investment, has a short time to retirement and expects tax rates to increase. In this paper we precisely identify situations when tax deferral is advantageous and disadvantageous.

The importance of this issue can be illustrated with some general statistics about the popularity of IRA's. In 2000 , over \$2.6 trillion were held in IRAs (\$2.4 trillion in traditional IRAs and \$77.6 billion in Roth IRA's). During the same tax year, over $\$ 36$ billion were contributed to IRAs ( $\$ 10.04$ billion to traditional IRAs, $\$ 11.56$ billion to Roth IRAs). In 2000, over 129 million taxpayers could technically make an IRA contribution, but less than 12 percent elected to contribute to an IRA (Sailer and Nutter, 2000). Further underscoring the importance of the issue is an aging U.S. population and increase in baby boomers reaching retirement age. The U.S. Census Bureau reported that 12 percent of the total population were age 65 or over in 2002, and estimated that approximately 20 percent of the total population will be age 65 and over by 2030 (U.S.C.B., 2003).

In this paper, we explore how various issues interact to determine if an individual should defer taxes. The remainder of the paper is organized as follows. Section 2 provides a summary of the relevant literature. A discussion of the possible future courses of tax rates follows in Section 3. Next the methodology and results of the paper are presented and discussed. Finally, Section 5 contains concluding comments.

\section{LITERATURE REVIEW}

Horan, Peterson and McLeod (1997) analyze the impact of declining marginal tax rates on investment choices. Their study evaluates the after-tax future value of nondeductible IRAs and taxable investments on comparable mutual funds by decreasing marginal tax rates from $31 \%$ to $28 \%$. They conclude that, holding marginal capital gain rates constant, increases in marginal tax rates favor taxable investments and decreases in marginal tax rates favor non-deductible investments. Burgess and Madeo (1980) model a break-even investment horizon and IRA withdrawals taking into account impact of withdraw penalties.

Randolph (1994) argues in favor of non-deductible IRAs over outright investment. He determines that IRAs performed better if invested in high turnover, high distribution mutual funds and the inverse holds true for taxable investments. Crain and Austin (1997) improve on Randolph's work by controlling for differences in ordinary income and capital gain tax rates. They conclude that deductible IRAs are more favorable for individuals who expect to be in a lower tax bracket upon retirement, while Roth IRAs are more favorable for those expecting to be in a higher tax bracket upon retirement. This finding is particularly interesting when taken together with the work of Bernheim, Skinner, and Wienberg (1997) who find that individual incomes drop by approximately 36 percent after retirement, and thus move the individual to lower marginal tax rates.

Krishnan and Lawrence (2001) examine IRAs, Roth IRAs, non-deductible IRAs and open taxable investments. They introduce a "break-even tax rate" which they define as the tax rate at withdrawal where alternate investments will produce the same future value for a given investment horizon and rate of return. That is, the tax rate that would make the individual indifferent between investing in a taxable or tax deferred account. They conclude that investors will benefit from deductible IRAs if they are in a low tax bracket at the time of the first withdrawal and that investors will benefit from Roth IRAs if they have longer investment horizons. In their comparison of non-deductible IRAs and open taxable investments, they conclude that investors with longer investment horizons benefit from nondeductible IRA's. However, non-deductible IRAs may become less desirable if an investor selects an investment instrument of which returns largely come from long-term capital gains.

Horan and Peterson (2001) improved on the Horan, Peterson, and McLeod (1997) model. Similar to Krishnan and Lawrence (2001), they assume that tax savings are invested in taxable investments, and allow for changes in tax brackets. They conclude that Roth IRAs and tax-deductible IRAs perform better when tax savings are invested in instruments that are not taxed at the ordinary income levels. Horan (2002) extends his prior work by 
introducing valuations based on annuitized patterns instead of single cash flow withdraws, and developing after-tax present value interest factors. Kutner, Doney and Trebby (2001) used the same equal before-tax investment as Crain and Austin (1997) to compare deductible IRAs and Roth IRAs and determined that the performance of both IRAs are affected by the individual's marginal tax rate at the beginning and at the end of the investment period.

Sibley (2002) uses capital investment theory to develop a more complex model that accounts for differences between deferred-tax and non-deferred tax assets to assist individuals' in valuing their asset mix. Specifically, his model determines the current non-deferred tax dollar equivalent of assets held in tax-deferred retirement accounts. He notes that "If a prospective retiree has specific expectations of future changes in either rates of return or tax rates, the general valuation process can be applied using an Excel spreadsheet that permits separate estimates of return and tax rate for each future year" (Sibley, 2002).

The work in this paper is most closely related to the work of Krishnan and Lawrence (2001), Sibley (2002), Burgess and Madeo (1980) and Horan (2002). Kirshnan and Lawrence (2001) and Burgess and Madeo (1980) solved for the break even tax rates and investment horizons respectively. The research in this paper extends this line of literature by identifying the break even return on investment. That is the return on investment that makes an individual indifferent between tax deferral and foregoing tax deferral. While Krishnan and Lawrence (2001) hold return constant and solve for the break-even tax rate, in this paper, tax rates are held constant and the break-even return on investment is solved for.

\section{THE FUTURE COURSE OF TAX RATES}

The future course of tax rates is unknown. Nevertheless, expectations about the future course of tax rates are critical in determining if an individual should defer taxes or not. As such, each individual must make an estimate about future tax rates in order to determine the optimal tax deferral strategy. To assist in this estimate, some information about the likely future course of tax rates can be gleaned from information that is currently available. Specifically, the current financial position of the federal government, and the historical record of tax rates provide clues about the likely future course of tax rates.

The federal government currently owes approximately 7.7 trillion dollars (Samuel, 2005). Current deficit spending was just over $\$ 500$ billion per year in fiscal year 2004 (Bureau of the Public Debt, 2005). This information indicates quite clearly that the combination of current tax rates and taxable economic activity are not sufficient to accommodate current spending patterns of the U.S. Government. There are at least four ways that U.S. Government deficit spending can be rectified. The first candidate is for tax rates to be increased or deductions decreased, thereby bringing additional funds into the system to offset the deficit. A second possibility is for the U.S. Government to undertake massive cuts in spending. If spending were cut sufficiently, current tax receipts may be sufficient to balance the budget. However, it is not likely that spending cuts of this size are possible as it would involve changes on the magnitude of eliminating the U.S. Defense Department. A third possibility is that the U.S. economy grows sufficiently so that associated increases in tax revenues would offset the budget deficit, in which case no tax rate increases would be necessary. A final, though remote, possibility is the U.S. Government defaulting on its debts. While U.S. Government bonds have long been considered a risk free investment, a remote possibility of a future U.S. Government default exists. It can be argued that this chance of default increases with the level of debt. If the U.S. were to default, eliminating the need to pay interest on the $\$ 7.7$ trillion dollars of public debt, current tax receipts may be sufficient to meet or exceed expenditures. Each of these solutions has merit and drawbacks. Which course the U.S. will follow is unknown. However, it is at least possible and probably likely that the solution will include some form of tax rate increases.

Others argue that the level of public debt has not reached a critical level. They argue that higher tax rates are not necessary. As long as the funds borrowed are for productive investments, there is little need to worry about the level of the deficit. Moreover, they may argue that a large amount of taxes have been deferred through the use of IRA's and other investment vehicles. These deferred taxes imply large future tax inflows for the federal government when the funds are removed from the accounts and taxed. In fact, some argue that lower tax rates are desirable even given the current federal debt level and budget deficits of the U.S. 
While many speculative arguments, such as those presented above can be forwarded regarding the possible future course of tax rates, perhaps the most compelling evidence regarding the likely future course of tax rates can be gleaned from a look at historical tax rates. Wilson and Jordan (2002), provide just such a historical analysis. They report the highest and lowest positive marginal tax rates from 1913 through 2002. Figure 1, created from data provided in Wilson and Jordan (2002), shows how the marginal tax rates have changed since 1913. The highest marginal tax rate for individuals started at seven percent in 1913. The rate gradually increased to 94 percent by the year 1944. The rate then was then reduced to 28 percent by 1988, and subsequently increased to 38.6 percent by 2002. The highest marginal tax rate remained at or above 70 percent during the entire period between 1936 and 1980 . The lowest positive marginal tax rate has shown similar shifts, starting at one percent in 1913, dipping to 0.375 percent in 1929, then increasing to 23 percent by 1944. The rate subsequently fell to 10 percent by 2002 . This historical evidence clearly shows that tax rates have changed dramatically throughout the history of the United States. Also noteworthy from Figure 1 is that the highest marginal tax rate has been more volatile than the lowest marginal tax rate throughout our history. The history of changes clearly indicates that future tax rates are by no means certain, and could take on highly varying values.

Given the arguments noted above along with the historical record of tax rates, the only things that are clear are that tax rates are likely to change in the future and the future course of tax rate changes is uncertain. Despite this uncertainty, investors must make an estimate about future tax rates and expected investment returns in order to make an informed decision concerning the extent to which tax deferral is a wise choice. This decision must be re-evaluated for each contribution and withdrawal date combination that the investor is considering.

As noted above, Bernheim, Skinner, and Wienberg (1997) find that individual incomes drop by approximately 36 percent after retirement, and thereby move the individual to lower marginal tax rates. Thus for many individuals, placing money in a tax deferred account has two benefits. First the benefit of tax deferral, and second the benefit of shifting incomes to a time when the individual will be in a lower tax bracket. While the equations developed in this paper are able to evaluate any such situations, this research is most beneficial to those individuals that will either maintain or increase their income levels in retirement and those that have shorter periods of time to retirement. With a large number of baby boomers now having a short amount of time to retirement, this research is particularly timely. The remainder of this paper focuses on how individual investors can make the tax deferral decision based on their own financial situation and expectations about the future course of tax rates.

Figure 1: The History Of United States Marginal Tax Rates From 1913 Through 2002

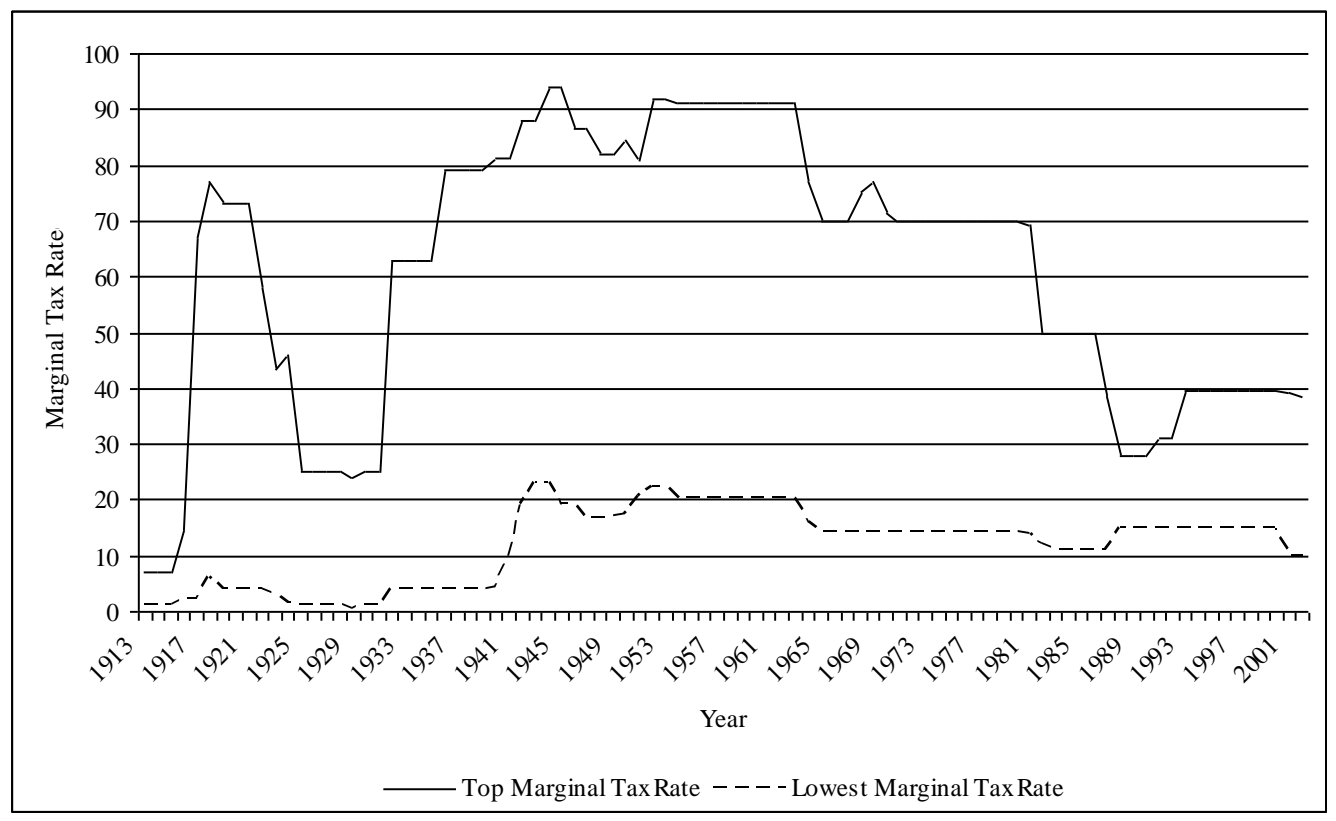




\section{METHODOLOGY AND RESULTS}

The optimal tax deferral strategy depends upon an investor's current tax rate, expectations about future tax rates, the time to retirement, and the expected rate of return on investment. In this paper, the number of years to retirement, the current tax rate and various estimates about future tax rates are taken as given. With this information, the indifference before tax return on investment (IROI) is computed. This indifference return on investment is the annual percentage return on investment that makes an investor indifferent between a tax deferred investment and a taxable investment given current and expected future tax rates as well as a known time until funds will be withdrawn from the accounts. For simplicity, we assume that there are no withdrawals from a tax deferred account that would trigger a penalty. It is also assumed that investments produce the same before tax rates of return in a tax deferred account or non-deferred account.

To determine the return on investment required to be indifferent about tax deferral, it is necessary to estimate the future course of tax rates. The analysis here is completed for each of three different assumptions about the future course of tax rates. In addition, a method for solving the problem for any other future tax rate and investment horizon combination is demonstrated. As such, this research has a broad scope, being applicable to investors with any current tax rate, expectation about the future course of tax rates and number of years to retirement.

The first tax assumption is that tax rates will make a permanent one time shift. The individual currently faces some tax rate on income from non-deferred investments, which can be any combination of capital gains and ordinary income tax rates. A tax rate shift will occur in the year following the initial investment to a new rate, that again may be any combination of the capital gains and ordinary income tax rate. The investor's tax rate will remain at that level through retirement on non-deferred income. Funds invested in a tax deferred account are subject to the future ordinary income tax rate of the investor, which may or may not equal the future tax rate on non-deferred investments. One instance of this tax rate scenario involves an investor that has observed the U.S. Congress make a tax rate change which takes effective in the following year.

The second assumption also involves an investor that is currently faced with any combination of capital gains and ordinary income tax rates on non-deferred income. Again, tax rates will make a permanent one time shift. However the second assumption is that the shift will occur after the last amount of interest has been earned, but before the funds have been withdrawn from the accounts. Any funds invested in a tax deferred account are subject to the future ordinary income tax rate, which may or may not equal the future rate on non-deferred income. As such, only the withdrawal from the tax deferred account will be subject to the new rates. An investor that expects a tax rate change in the distant future might base his decisions on the results of this second analysis.

The third assumption involves an investor that is currently faced with any combination of capital gains and ordinary income tax rates on non-deferred income. This rate will remain constant at its current level for one year. After one year, the rate will increase in equal annual increments until it reaches a new higher or lower rate. This new tax rate on non-deferred income will be the future ordinary income tax rate that prevails at the time funds are withdrawn from the accounts. Funds invested a tax deferred account are subject to the future ordinary income tax rate of the individual. Many individuals are advised to gradually shift their portfolio from capital gains producing assets to income producing assets as they age. These individuals could find themselves in a situation at retirement where both, returns from non-deferred assets and withdrawals from tax deferred accounts are taxed at the same rate, the then prevailing ordinary income tax rate.

These three assumptions are not exhaustive as any number of other assumptions about the future course of tax rates can be considered. We provide analysis tools to assist the investor in computing (IROI) under any other tax rate assumption not specifically solved for here. Moreover, while we use a specific combination of rates and time to retirement here, the problem can be solved for any other rate combination or times to retirement that might occur. The three tax assumptions are illustrated in Table 1 where current tax rates on non-deferred income faced by the investor in 2005, which can be any combination of ordinary and capital gains rates, are 15 percent. These rates are expected to rise so that the future rate on income from non-deferred investments is 20 percent. The future ordinary income tax rate is 25 percent in 2008. Using the three assumptions outlined above, the future value of each, an investment in a tax 
deferred account and an investment in a non-tax deferred account are computed. Next, these future values are equated and the resulting equation is solved for the IROI. This is done for several combinations of current tax rates and expected future tax rates. By examining these tables and formulas, investors can determine if tax-deferral is appropriate given a current tax rate, expectation about future tax rates and time to retirement.

Table 1: Future Course Of Tax Rates

\begin{tabular}{|c|c|c|c|}
\hline Year & One Time Shift Beginning & $\begin{array}{c}\text { One Time Shift } \\
\text { End }\end{array}$ & Incremental Change \\
\hline 2005 & $15 \%$ & $15 \%$ & $15 \%$ \\
\hline 2006 & $20 \%$ & $15 \%$ & $15 \%$ \\
\hline 2007 & $20 \%$ & $15 \%$ & $20 \%$ \\
\hline 2008 & $20 \%(25) \%$ & $15 \%(25 \%)$ & $25(25) \%$ \\
\hline
\end{tabular}

For demonstration purposes, consider an investor who has $\$ 30,000$ from current earnings to invest today. Through various deferment vehicles, the individual is able to defer the entire amount if he/she so chooses. The investor has a five year investment horizon. His/her current tax rate is $15 \%$ on non-deferred income. The investor expects the future tax rate on non-deferred income to be 20 percent. The investor expects the future tax rate on deferred income, the ordinary income tax rate, to be 25 percent. The investor expects to earn a 10 percent annual ROI either in a tax deferred, or non-tax deferred account. Income from the tax deferred investment will be taxed at the future ordinary income rate, while income from the non-deferred account will be taxed at the future non-deferred tax rate. The investor wishes to determine if it is preferable to invest through a tax-deferred account or pay taxes currently and invest the remaining proceeds. We complete the analysis using each of the assumptions about the course of future taxes outlined above.

\section{One Time Shift Beginning}

Recall that the first tax assumption is that tax rates will make a permanent, one time, shift. The shift will occur in the year following the initial investment and remain at that level through retirement. First, the future value of the individuals investments are computed if taxes are deferred and if taxes are not deferred. The analysis begins with the tax deferral case. The investor that defers taxes places all of his/her currently saved retirement funds in a tax deferred account. The individual will leave the funds in this account until retirement. At retirement, the individual removes the funds from the account. The individual then pays taxes at the ordinary income tax rate that prevails at the time funds are withdrawn from the account. The individual uses the funds at this point as desired. While the analysis here assumes the individual removes the funds from the account upon retirement, the analysis is also relevant for individuals who wish to delay withdrawal of the funds until some time after retirement. Consider an individual that has currently saved some money which is intended for use in retirement, $S$. The investor expects to earn an annual rate of return of $i$, on the investments and has an investment horizon of $n$. If the investor defers taxes, at the time of withdrawal, and before paying taxes, the individual will have the future value of his investments $B T F V$, available as:

$$
B T F V_{n}=S(1+i)^{n}
$$

The individual will then pay taxes at the ordinary income tax rate that prevails in the future, TOf, leaving the individual with the after tax future value $A T F V$, which can be used by the investor as desired. This amount is computed as:

$$
A T F V_{n}=B T F V(1-T O f)
$$


Combining equations 1 and 2 gives:

$$
A T F V_{n}=S(1+i)^{n}(1-T O f)
$$

For the investor described above, at retirement the individual will have:

$$
A T F V_{n}=\$ 30,000(1+.10)^{5}(1-.25)=\$ 36,236.48
$$

If the individual does not defer taxes, the investor pays taxes on the funds today at the current combination of capital gains and ordinary income tax rates that the investor is faced with, $T c$, and invests the remaining proceeds. The amount of money available to invest today after tax, $F I$ is:

$$
F I=S(1-T c)
$$

In addition to taxes on the principal amount, the investor pays taxes each year on the earnings at the rate $T G f$, which can again be any combination of ordinary or capital gains tax rates that the investor is faced with in the future. The future value of the savings after paying these taxes is computed as:

$$
A T F V_{n}=F I\{1+[i *(1-T G f)]\}^{n}
$$

Combining Equations, 4 and 5 gives:

$$
A T F V_{n}=S(1-T c)\left\{1+[i *(1-T G f)\}^{n}\right.
$$

For the investor described above the amount of money available at the end of the investment horizon is:

$$
A T F V_{n}=\$ 30,000(1-0.15)\left\{1+[0.10 *(1-0.2)\}^{5}=\$ 37,467.87\right.
$$

At the end of the investment horizon, the investor removes this $\$ 37,467.87$ from the account and spends it as he/she chooses. In this example, the return on the additional funds available by tax deferring is not sufficient to offset the increase in tax rates, so the investor should not defer. The difference in future values is $\$ 1,231.39(\$ 37,467.87$ $\$ 36,236.48$ ). However, this will not always be the case. In the event that the individual is able to earn a higher return, or has a longer time until retirement, it may be better to defer taxes even in the presence of increasing tax rates.

The analysis here assumes that the individual removes the entire amount of money from the account on a given day. In reality, many investors deposit and withdraw funds from their retirement accounts in the form of annuities or other multi-payment patterns. The equations developed here can accommodate such situations. To do so requires a separate analysis for each contribution and withdrawal date combination. For example, suppose that a 50year old individual deposits $\$ 4,000$ into an IRA for retirement. He/she intends to withdraw some of these funds along with the associated earnings from the account at age 69 and the remainder at age 70 . In the current framework this problem involves two independent decisions. To analyze the problem it is necessary to compute the solution once for each intended withdrawal date. Similarly, an individual with multiple deposit dates, would re-compute the solution for each deposit date.

To summarize the computations, a formula is developed to solve specifically for the IROI. The solution is obtained by equating, the future value of the tax deferral alternative to the future value of the non-tax deferral alternative as follows:

$$
S(1+i)^{n}(1-T O f)=S(1-T c)\{1+[i *(1-T G f)]\}^{n}
$$


Solving Equation 7 for $i$, gives Equation 8, the return on investment at which the individual will be indifferent between tax deferral and non tax deferral (IROI):

$$
I R O I=\frac{\left(\frac{(1-T O f)}{(1-T c)}\right)^{\frac{1}{n}}-1}{1-T G f-\left(\frac{(1-T O f)}{(1-T c)}\right)^{\frac{1}{n}}}
$$

Equation 8 allows an individual to easily compute the IROI given his specific tax situation and investment horizon. The equation can easily be applied to any combination of current tax rates, expected future tax rates, and time to retirement. For the investor discussed above with a 15 percent current tax rate, a 20 (25) percent future tax rate and a five-year investment horizon, the equation is computed as:

$$
I R O I=\frac{\left(\frac{(1-0.25)}{(1-0.15)}\right)^{\frac{1}{5}}-1}{1-0.20-\left(\frac{(1-0.25)}{(1-0.15)}\right)^{\frac{1}{5}}}=0.1410
$$

If the individual expects to earn a 14.1 percent ROI on his investments, he will be indifferent about deferral. If the investor expects his return to be above the rate computed by Equation 8, the individual is better off by deferring taxes. If the investor expected his return to be below the rate computed by Equation 8, the individual is better off without deferral. Given historical average returns on the U.S. stock market between 10-11 percent (Ibbotson and Chen, 2003), exceeding a 14.1 percent return should not to be taken lightly. Table 2 demonstrates the computations for various combinations of tax rates for an individual with 5 years until funds with be withdrawn from the accounts. Because there are three tax rates involved, the table is presented for three possible future tax rates on non-deferred income, $10 \%, 15 \%$ and 20\%, in Panels A, B, and C, respectively. In each panel, the IROI is solved for varying combinations of the current tax rate and expected future tax rate on ordinary income. For example if the current tax rate is 15 percent, the future ordinary income tax rate is 25 percent, and the future tax rate on non-deferred income is 10 percent the indifference ROI is 32.84 percent. If the investor expects to achieve a 32.84 percent ROI, he/she will be indifferent about tax deferral. Any time the investor expects to earn above 32.84 percent on his investments, tax deferral is preferable. If he expects to earn less than 32.84 percent on his investments, tax deferral is not preferable.

Additional tables, covering other times to retirement and tax rates, are available from the authors by request. However, in general it can be said that as the number of years to retirement increases, the IROI will decline. For example, if the above described investor had 20 years to retirement, the IROI would be 6.65 percent. The careful reader will note that some combinations having low current tax rates and high future tax rates are omitted and labeled NM (Not Meaningful). These cells were labeled as such, as the equation turned negative. While the rate is not meaningful, the individual would clearly not want to defer taxes in such situations.

\section{One Time Shift at the End of the Period}

Recall that the second tax assumption was that the tax rate remains unchanged throughout the pre-retirement years, but makes a sudden shift, after all income has been earned, but prior to withdrawing funds from the account. Under this tax assumption, the IROI is computed as: 


$$
I R O I=\frac{\left(\frac{(1-T O f)}{(1-T c)}\right)^{\frac{1}{n}}-1}{1-T c-\left(\frac{(1-T O f)}{(1-T c)}\right)^{\frac{1}{n}}}
$$

Again, using the investor discussed above with a 15 percent current tax rate, $T c$, a 20 percent future ordinary income tax rate, $T O f$, and five years to retirement, the equation is computed as:

$$
I R O I=\frac{\left(\frac{(1-0.25)}{(1-0.15)}\right)^{\frac{1}{5}}-1}{1-0.15-\left(\frac{(1-0.25)}{(1-0.15)}\right)^{\frac{1}{5}}}=0.1973
$$

The indifference ROI is 19.73 percent. If the individual can earn above 19.73 percent on his investments it is better to defer taxes. At rates below 19.73 percent it is best to avoid tax deferral. It is interesting to note in this case that the timing of the tax rate shift makes a 563 basis point difference (.1973-.1410) in the IROI. Table 3 demonstrates the computations at various combinations of tax rates for an individual with 5 years to retirement. The careful reader will notice that $T G f$ is not included in Equation 9. This is no accident. Indeed, all earnings from the non-deferred account would be taxed at the currently prevailing rate of $T c$, under the second tax assumption. 
Table 2: Indifference ROI For A 5-Years To Retirement And A One-Time Tax Rate Shift At The Beginning Of The Investment Horizon

\begin{tabular}{|c|c|c|c|c|c|c|c|c|c|c|c|}
\hline \multicolumn{12}{|c|}{ Panel A: $10 \%$ Future Tax Rate on Non-Deferred Income } \\
\hline \multicolumn{12}{|c|}{ Future Tax Rate on Deferred Income } \\
\hline \multirow{11}{*}{ 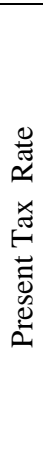 } & $\mathbf{0}$ & 5 & 10 & 15 & 20 & 25 & 30 & 35 & 40 & 45 & 50 \\
\hline & 5 & 0.00 & 12.05 & 28.20 & 51.03 & 85.80 & 145.39 & 271.60 & 720.31 & NM & NM \\
\hline & 10 & -9.81 & 0.00 & 12.82 & 30.35 & 55.78 & 96.16 & 170.36 & 352.33 & 1512.9 & NM \\
\hline & 15 & -18.36 & -10.31 & 0.00 & 13.70 & 32.84 & 61.52 & 109.38 & 205.72 & 501.73 & $\mathrm{NM}$ \\
\hline & 20 & -25.91 & -19.25 & -10.87 & 0.00 & 14.71 & 35.78 & 68.57 & 126.82 & 259.71 & 872.56 \\
\hline & 25 & -32.62 & -27.08 & -20.22 & -11.50 & 0.00 & 15.88 & 39.30 & 77.45 & 150.92 & 352.33 \\
\hline & 30 & -38.64 & -34.01 & -28.36 & -21.30 & -12.20 & 0.00 & 17.25 & 43.60 & 88.99 & 186.37 \\
\hline & 35 & -44.09 & -40.21 & -35.53 & -29.78 & -22.50 & $\begin{array}{l}-12.99 \\
\end{array}$ & 0.00 & 18.88 & 48.94 & 104.58 \\
\hline & 40 & -49.05 & -45.79 & -41.91 & -37.20 & -31.34 & -23.84 & -13.90 & 0.00 & 20.85 & 55.78 \\
\hline & 45 & -53.60 & -50.86 & -47.63 & -43.76 & -39.02 & -33.07 & -25.36 & -14.93 & 0.00 & 23.28 \\
\hline & 50 & -57.80 & -55.51 & -52.82 & -49.64 & -45.79 & -41.04 & -35.01 & -27.08 & -16.14 & 0.00 \\
\hline \multicolumn{12}{|c|}{ Panel B: $15 \%$ Future Tax Rate on Non-Deferred Income } \\
\hline \multicolumn{12}{|c|}{ Future Tax Rate on Deferred Income } \\
\hline \multirow{5}{*}{ 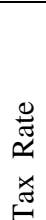 } & $\mathbf{0}$ & 5 & 10 & 15 & 20 & 25 & 30 & 35 & 40 & 45 & $\mathbf{5 0}$ \\
\hline & 5 & 0.00 & 7.72 & 17.19 & 29.07 & 44.48 & 65.29 & 95.03 & 141.19 & 222.90 & 408.01 \\
\hline & 10 & -6.76 & 0.00 & 8.20 & 18.37 & 31.36 & 48.55 & 72.44 & 108.02 & 166.90 & 283.73 \\
\hline & 15 & -13.04 & -7.12 & 0.00 & 8.74 & 19.73 & 34.03 & 53.44 & 81.36 & 125.16 & 204.19 \\
\hline & 20 & -18.90 & -13.71 & -7.52 & 0.00 & 9.35 & 21.31 & 37.21 & 59.43 & 92.80 & 148.83 \\
\hline \multirow{6}{*}{$\begin{array}{l}\text { च्य } \\
\text { D. } \\
\text { D. }\end{array}$} & 25 & -24.40 & -19.84 & -14.46 & -7.97 & 0.00 & 10.05 & 23.17 & 41.04 & 66.94 & 108.02 \\
\hline & 30 & -29.57 & -25.58 & -20.88 & -15.29 & -8.48 & 0.00 & 10.87 & 25.38 & 45.76 & 76.64 \\
\hline & 35 & -34.46 & -30.95 & -26.87 & -22.04 & -16.22 & -9.05 & 0.00 & 11.84 & 28.05 & 51.70 \\
\hline & 40 & -39.09 & -36.03 & -32.48 & -28.31 & -23.33 & -17.27 & -9.71 & 0.00 & 13.00 & 31.36 \\
\hline & 45 & -43.50 & -40.83 & -37.75 & -34.16 & -29.91 & -24.78 & -18.47 & -10.48 & 0.00 & 14.40 \\
\hline & 50 & -47.73 & -45.40 & -42.74 & -39.65 & -36.03 & -31.70 & -26.43 & -19.84 & -11.37 & 0.00 \\
\hline \multicolumn{12}{|c|}{ Panel C: $20 \%$ Future Tax Rate on Non-Deferred Income } \\
\hline \multicolumn{12}{|c|}{ Future Tax Rate on Deferred Income } \\
\hline \multirow{11}{*}{ 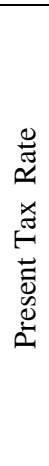 } & $\mathbf{0}$ & 5 & 10 & 15 & 20 & 25 & 30 & 35 & 40 & 45 & $\mathbf{5 0}$ \\
\hline & 5 & 0.00 & 5.68 & 12.36 & 20.33 & 30.02 & 42.09 & 57.59 & 78.27 & 107.35 & 151.49 \\
\hline & 10 & -5.16 & 0.00 & 6.03 & 13.17 & 21.81 & 32.47 & 46.00 & 63.79 & 88.32 & 124.49 \\
\hline & 15 & -10.11 & -5.44 & 0.00 & 6.41 & 14.10 & 23.52 & 35.35 & 50.70 & 71.50 & 101.39 \\
\hline & 20 & -14.88 & -10.65 & -5.75 & 0.00 & 6.85 & 15.18 & 25.53 & 38.80 & 56.49 & 81.35 \\
\hline & 25 & -19.49 & -15.66 & -11.25 & -6.10 & 0.00 & 7.36 & 16.42 & 27.92 & 43.01 & 63.79 \\
\hline & 30 & -23.95 & -20.49 & -16.53 & -11.92 & -6.50 & 0.00 & 7.94 & 17.90 & 30.79 & 48.24 \\
\hline & 35 & -28.28 & -25.16 & -21.60 & -17.49 & -12.68 & -6.95 & 0.00 & 8.63 & 19.66 & 34.34 \\
\hline & 40 & -32.49 & -29.69 & -26.51 & -22.85 & -18.58 & -13.54 & -7.47 & 0.00 & 9.44 & 21.81 \\
\hline & 45 & -36.61 & -34.10 & -31.26 & -28.01 & -24.24 & -19.81 & -14.52 & -8.07 & 0.00 & 10.42 \\
\hline & 50 & -40.65 & -38.41 & -35.89 & -33.01 & -29.69 & -25.82 & -21.22 & -15.66 & -8.78 & 0.00 \\
\hline
\end{tabular}


Table 3: Indifference ROI For A 5-Years To Retirement And A One-Time Tax Rate Shift At The End Of The Investment Horizon

\begin{tabular}{|c|c|c|c|c|c|c|c|c|c|c|c|}
\hline \multicolumn{12}{|c|}{ Future Tax Rate on Deferred Income } \\
\hline \multirow{11}{*}{ 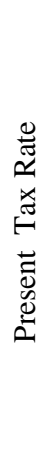 } & $\mathbf{0}$ & 5 & 10 & 15 & 20 & 25 & 30 & 35 & 40 & 45 & 50 \\
\hline & 5 & 0.00 & 27.41 & 78.57 & 208.38 & 1208.1 & NM & NM & NM & NM & NM \\
\hline & 10 & -9.81 & 0.00 & 12.82 & 30.35 & 55.78 & 96.16 & 170.36 & 352.33 & 1512.92 & NM \\
\hline & 15 & -13.04 & -7.12 & 0.00 & 8.74 & 19.73 & 34.03 & 53.44 & 81.36 & 125.16 & 204.19 \\
\hline & 20 & -14.88 & -10.65 & -5.75 & 0.00 & 6.85 & 15.18 & 25.53 & 38.80 & 56.49 & 81.35 \\
\hline & 25 & -16.22 & -12.93 & -9.21 & -4.94 & 0.00 & 5.80 & 12.72 & 21.15 & 31.68 & 45.26 \\
\hline & 30 & -17.35 & -14.66 & -11.66 & -8.28 & -4.43 & 0.00 & 5.16 & 11.26 & 18.62 & 27.70 \\
\hline & 35 & -18.39 & -16.12 & -13.61 & -10.81 & -7.66 & $\begin{array}{r}-4.09 \\
\end{array}$ & 0.00 & 4.75 & 10.36 & 17.10 \\
\hline & 40 & -19.40 & -17.44 & -15.28 & -12.90 & -10.24 & -7.26 & -3.88 & 0.00 & 4.51 & 9.83 \\
\hline & 45 & -20.43 & -18.70 & -16.82 & -14.74 & -12.45 & -9.89 & -7.02 & -3.75 & 0.00 & 4.38 \\
\hline & $\mathbf{5 0}$ & -21.50 & -19.97 & -18.30 & -16.47 & -14.45 & -12.22 & -9.73 & -6.91 & -3.71 & 0.00 \\
\hline
\end{tabular}

\section{Others Tax Rate Changes}

Under the third assumption, tax rates will remain constant at their current level for one year. After one year, rates will increase in equal annual increments to a new rate. This new rate will equal the future ordinary income tax rate. Funds withdrawn from a tax-deferred account will also be subject to the future ordinary income tax rate on withdrawal. The mathematics for developing a formula to solve for the IROI in this situation is complex. Many other possible combinations involve complex mathematical solutions. In these instances, it may be easier to solve for the IROI by using the Solver function in Microsoft Excel or other similar program as opposed to explicitly developing a formula for the IROI. This approach was suggested by Sibley (2002). The procedure for using Excel Solver is demonstrated using the third tax assumption. This procedure can be easily adapted for any other tax rate combinations that an investor might expect to occur in the future.

To use solver for computing the IROI, first the future value of the tax deferred cash flows and the non-tax deferred cash flows are computed for a certain number of years to retirement, current tax rate, future tax rate and return on investment. Next the difference between the two future values is computed. Finally, the solver function in Excel is used to vary the return on investment until the difference in future values is zero. For the investor with a 15 percent current tax rate, 20 percent future tax rate on deferred income or non-deferred income, and 5 years to retirement, the indifference ROI is 7.40 percent: Table 4 shows IROI computations for an individual with 5 years to retirement at different tax rate combinations.

Table 4: Indifference ROI For A 5-Years To Retirement And A Gradual Tax Rate Shift

\begin{tabular}{|c|c|c|c|c|c|c|c|c|c|c|c|}
\hline \multicolumn{12}{|c|}{ Future Tax Rate on Deferred Income and Non-Deferred Income } \\
\hline \multirow{11}{*}{ 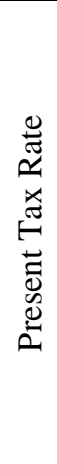 } & $\mathbf{0}$ & 5 & 10 & 15 & 20 & 25 & 30 & 35 & 40 & 45 & $\mathbf{5 0}$ \\
\hline & 5 & 0.00 & 16.74 & 28.15 & 36.88 & 44.14 & NM & NM & NM & NM & $\mathrm{NM}$ \\
\hline & 10 & -12.66 & 0.00 & 10.00 & 18.36 & 25.67 & 32.33 & 38.62 & $\mathrm{NM}$ & $\mathrm{NM}$ & $\mathrm{NM}$ \\
\hline & 15 & -18.38 & -8.42 & 0.00 & 7.40 & 14.10 & 20.35 & 26.34 & 32.24 & 38.19 & 44.37 \\
\hline & 20 & -21.91 & -13.72 & -6.52 & 0.00 & 6.04 & 11.78 & 17.34 & 22.86 & 28.45 & 34.26 \\
\hline & 25 & -24.50 & -17.53 & -11.25 & -5.46 & 0.00 & 5.24 & 10.38 & 15.50 & 20.72 & 26.14 \\
\hline & 30 & -26.61 & -20.54 & -14.98 & $\begin{array}{l}-9.77 \\
\end{array}$ & -4.81 & 0.00 & 4.74 & 9.50 & 14.35 & 19.41 \\
\hline & 35 & -28.49 & -23.10 & -18.10 & -13.37 & -8.83 & -4.39 & 0.00 & 4.42 & 8.95 & 13.67 \\
\hline & 40 & -30.25 & -25.39 & -20.84 & -16.51 & -12.32 & -8.21 & -4.13 & 0.00 & 4.23 & 8.64 \\
\hline & 45 & -31.97 & -27.54 & -23.36 & -19.36 & -15.47 & -11.65 & $\begin{array}{l}-7.83 \\
\end{array}$ & -3.97 & 0.00 & 4.14 \\
\hline & 50 & -33.71 & -29.63 & -25.76 & -22.04 & -18.42 & -14.84 & -11.25 & -7.62 & -3.89 & 0.00 \\
\hline
\end{tabular}




\section{CONCLUDING COMMENTS}

In this paper the concept of an indifference return on investment (IROI) is introduced. This IROI is the rate of return at which an investor is indifferent about tax deferral given a current tax rate, expected future tax rate and time to retirement. This work extends the work of others who have solved for indifference tax rates and indifference investment horizons. The sensitivity of the results to differences in the timing of an expected tax rate change are computed. Over a five-year horizon, differences in the timing of a tax rate change are found to make a 563 basis point difference in the IROI for an investor with a current tax rate of 15 percent, an expected future tax rate on non-deferred income of 20 percent and a future tax rate on deferred income of 25 percent. Formulas and tables are presented to assist investors in determining their IROI for various tax rate combinations. Solving for the IROI under a variety of other tax rate and year to retirement combinations are also demonstrated using Excel Solver. This research provides investors a more comprehensive understanding of the factors that determine optimal tax deferral choices and will permit investors to make better choices about tax deferral. There are many open research questions related to tax deferral, however; the research presented here fills one important gap in the literature.

The authors wish to thank Mr. Victor Hugo-Cordero and Karla Jessica Cordero-Madriz for their valuable research assistance in solving equations 8 and 9.

\section{REFERENCES}

1. Bernheim, B.D., Skinner, J.S., and Weinberg, S. (1997) What Accounts for the Variation in Retirement Wealth Among U.S. households? Mimeo (Stanford University)

2. Bureau of Public Debt Website: http://www.publicdebt.treas.gov/ downloaded May 15, 2005.

3. Burgess, R.D. and Madeo, S.A. (1980) A Simulation study of tax Sheltered Retirement Plans, Journal of American Taxation, vol. 1, p. 34-41.

4. Crain, T.L. and Austin J.R. (1997) An analysis of Tradeoff Between Tax Deferred Earnings in IRAs and Preferential Capital Gains, Financial Service Review, vol. 6(4), p. 228-229.

5. Horan, S.M., and J.H. Peterson (2001) A Reexamination of tax-Deductible IRAs, Roth IRAs, and 401(k) Investments, Financial Services Review, vol. 10, p. 87-100.

6. Horan, S.M. and J.H. Peterson, and R. McLeod (1997) An Analysis of Nondeductible IRA Contributions and Roth IRA Conversions, Financial Services Review vol 6(4) p. 243-256.

7. Horan, S.M. (2002) After-Tax Valuation of Tax-Sheltered Assets, Financial Services Review, vol. 11, p. $253-275$.

8. Ibbotson, Roger and Peng Chen (2003) Stock Market Returns in the Long Run, Participating in the Real Economy, Financial Analysts Journal, vol. 59(1), January/February p. 26-33.

9. Krishnan, S.V. and Lawrence, S. (2001) Analysis of Investment Choices for Retirements: A New Approach and Perspective, Financial Service Review, vol. 10(1) p. 75-86.

10. Kutner, G.W., Doney, L.D., Trebby, J.P. (2001) Investment Performance comparison between Roth and Traditional Individual Retirement Accounts, Journal of Applied Business Research, vol. 17(1), p. 55-60.

11. Randolph, W.L. (1994) The Impact of Mutual Fund Distributions on After-Tax Returns, Financial Services Review vol. 3(2) p. 38-42.

12. Sailer, P.J. and Nutter S.E. (2992) Accumulation and Distribution of Individual Retirement Arrangements, Internal Revenue Service. 2002. P. 121. http://www.irs.gov/pub/irs-soi/00retire.pdf

13. Samuel Terence (2005) The American Prospect, $\$ 7,782,816,546,352$ in Debt, CBS News, http://www.cbsnews.com/stories/2005/04/08/opinion/main686839.shtml

14. Sibley, M. (2002) On the Valuation of Tax-Advantaged Retirement Accounts, Financial Services Review, vol. 11(3), p. $233-251$.

15. U.S. Census Bureau (2003) Special Edition-Social Security COLA: CB03-FF.19SE December 11. http://www.census.gov/PressRelease/www/releases/archives/facts_for_features/001583.html

16. U.S. Internal Revenue Service. Publication 590. 2004. http://www.irs.gov/publications/p590/ch01.html\#d0e922

17. Wilson, Robert A. and David E. Jordan (2002) Personal Exemptions and Individual Income Tax Rates, 1913-2003, Rev. 6-02), Internal Revenue Service Statistics of Income Bulletin, Publication 1136 (Spring), p. 216-225. 